\title{
GENETIC CONTROL OF PLANT ARCHITECTURE IN THE COMMON BEAN (Phaseolus vulgaris L.)
}

\author{
Flavia França Teixeiral', Magno Antonio Patto Ramalhol and Ângela de Fátima Barbosa Abreu
}

\begin{abstract}
More erect plant architecture has been a goal in the development of bean cultivars. Aiming to obtain more information about genetic control of traits related to plant architecture, this work was carried out between August 1995 and July 1997 in the southern and Alto São Francisco regions, in the State of Minas Gerais, Brazil. Initially, analyses were performed with individual plants of parents and different segregant generations from the crosses Carioca-MG x H-4 and Carioca x FT-Tarumã. In these experiments, besides degree of erectness, other traits were evaluated: ramification degree, internode length, internode diameter and height of insertion of the first pod. Mean and variance components and heritability at an individual level were estimated. Later, families derived from $\mathrm{F}_{2}$ or $\mathrm{F}_{3}$ plants of the same crosses were evaluated for degree of erectness. Genetic and phenotypic variance between family averages, heritabilities using variance components, and realized heritability were estimated. Of the morphological traits, internode length varied the most. There was a predominance of additive effect in the control of this trait. Evaluating plant architecture with individual plants for degree of erectness was not efficient. However, when families were used, genetic parameter estimates confirmed the possibility of successful selection, especially if evaluated for a few generations and/or environments, despite the strong environmental influence on trait expression.
\end{abstract}

\section{INTRODUCTION}

Some of the advantages of upright plant architecture in common bean cultivars are greater tolerance to lodging, reduced harvest losses, reduced susceptibility to diseases such as white mold, and facilitation of culture management and mechanized harvest. Beans from the cultivars now available with good plant architecture have a low market value. For this reason, breeding programs have emphasized the combination of ideal plant architecture with other desirable agronomical traits in the same cultivar. However, the insufficiency of information on genetic control of bean architecture and traits related to architecture impedes progress toward an ideal cultivar.

The definition of bean architecture is based on morphological traits, but there is no consensus as to which traits should be given priority in its determination. Acquaah et al. (1991) recommended the use of plant height, hypocotyl diameter, ramification angle and pod distribution in the middle section of the plant, while Brothers and Kelly (1993) used ramification angle, hypocotyl diameter and plant height. A scale of grades considering the plant as a whole has also been developed (Collicchio et al., 1997).

There has been some work done to clarify genetic control of traits that influence bean plant architecture (Davis and Frazier, 1966; Santos and Vencovsky, 1986; Singh, 1991). However, they only studied individual traits associated with plant architecture. We decided to study the genetic control of bean architecture and associated multiple morphological traits.

\footnotetext{
${ }^{\prime}$ Departamento de Biologia, Universidade Federal de Lavras, Caixa Postal 37, 37200-000 Lavras, MG, Brasil.

${ }^{2}$ Embrapa/EPAMIG, Caixa Postal 176, 37200-000 Lavras, MG, Brasil. Send correspondence to A.F.B.A.
}

\section{MATERIAL AND METHODS}

Segregating populations were compared from 1995 to 1997 at the campus of the Federal University of Lavras (UFLA). Data were gathered at the experimental farm of the 'Fundação de Apoio a Pesquisa' (FAEPE), both in Lavras, MG, Brazil (21 ${ }^{\circ} 12^{\prime}$ ' south, $45^{\circ} 00^{\prime}$ west and $910 \mathrm{~m}$ altitude) and at the research station of the 'Empresa de Pesquisa Agropecuária de Minas Gerais' (EPAMIG) in Patos de Minas, Brazil (18 $35^{\prime}$ 'south, $46^{\circ} 31^{\prime}$ 'west, $856 \mathrm{~m}$ altitude).

Four parents with different agronomical traits were used to obtain the segregating populations (Table I). Experiments were carried out evaluating individual plants and families. The experiments evaluating individual plants were sown in July of 1996. In the first experiment, the $\mathrm{F}_{1}, \mathrm{~F}_{2}, \mathrm{~F}_{3}, \mathrm{~F}_{2} \mathrm{BC}_{1}, \mathrm{~F}_{2} \mathrm{BC}_{2}$ generations and the parents of the Carioca MG x H-4 cross were evaluated in Patos de Minas. In the second experiment (Carioca x FT-Tarumã cross) the same generations, except $\mathrm{F}_{2}$, were studied in Lavras. In both experiments a random complete block design was used, with three replications. Ninety plants were evaluated from each parental and $\mathrm{F}_{1}$ generation and 270 plants from the $\mathrm{F}_{2}, \mathrm{~F}_{3}, \mathrm{~F}_{2} \mathrm{BC}_{1}$ and $\mathrm{F}_{2} \mathrm{BC}_{2}$ generations. The following traits were evaluated: degree of branching, with plants containing up to three basal ramifications classified as little ramified and those with more than three basal ramifications as very ramified; length from the 4th to 7th internode; 5th internode diameter; height of insertion of the first pod, which was measured from the soil level to the apex of the lowest pod; and degree of erectness on a scale of 1 to 9 . Value 1 corresponded to the most erect plant and value 9 to the most prostrate. Mean and variance components were estimated (Mather and Jinks, 1984; Ramalho et al., 1993), and narrow sense heritability 
was estimated from the variance components, based on an individual level.

Four experiments on plant architecture were carried out using bean families (Table II). Genetic variance in each generation and broad sense heritability of the families were estimated based on the expected mean squares. The realized heritability from evaluating the same families in more than one generation and/or location was estimated using the procedure presented by Fehr (1987).

\section{RESULTS}

Mean and variance component estimates were determined for individuals (Table III). The genetic model of averages was sufficient to explain observed variations for most traits, since $r^{2}$ was higher than 0.50 . In the CariocaMG x H-4 cross, the additive component estimate (a) differed significantly from zero for the traits ramification degree, length from the 4th to 7 th internode and degree of erectness. This indicates a predominantly additive effect for these traits. The additive $\mathrm{x}$ additive interaction component for ramification degree, in addition to the additive component was also significantly different from zero. Additive genetic variance estimates were significantly different from zero for the traits length from the 4th to 7 th internode, 5th internode diameter and plant architecture grade. Heritability estimates were low and had associated errors superior to the estimates.

Table I - Bean lines used and their relevant traits.

\begin{tabular}{|lcl|}
\hline Lines & \multicolumn{2}{c|}{ Traits } \\
\cline { 2 - 3 } & Growth habit $^{1}$ & \multicolumn{1}{c}{ Bean type } \\
\hline Carioca-MG & II & small and beige with brown stripe \\
Carioca & III & small and beige with brown stripe \\
H-4 & III & small and beige with brown stripe \\
FT-Tarumã & II & small and black \\
\hline
\end{tabular}

${ }^{1}$ II: plant with indeterminate habit, upright; III: plant with indeterminate habit, weak-stemmed, non-climber or semi-climbing.
In the Carioca-MG x FT-Tarumã cross, an additive effect was observed for the traits length from the 4th to 7 th internode, 5th internode diameter, plant architecture grade and height of insertion of the first pod. The 5th internode diameter, besides the additive effect, presented dominance effects and a dominant $\mathrm{x}$ dominant interaction. In this cross, additive variance was present for length from the 4th to 7th internode, 5th internode diameter and height of insertion of the first pod. Dominance variance was also observed for ramification degree and degree of erectness. Also in this case, the length from the 4th to 7 th internode was highly heritable, while for the traits 5th internode diameter and height of insertion of the first pod, heritability estimates were of small magnitude and associated with elevated errors.

In all experiments involving families, heritability estimates were high, above $29 \%$, and associated with relatively small errors (Table IV). Heritability estimates were expressed with higher confidence when the same generation was evaluated at more than one location, especially when compared to the estimates in the individual plant evaluations. There was also variability in the amplitude of degree of erectness obtained in the segregant families (Table IV).

In the Carioca-MG x H-4 cross in Lavras, selection in $\mathrm{F}_{2 \cdot 3}$ during the winter of 1996 and evaluation in $\mathrm{F}_{2 \cdot 4}$ during the dry season presented null heritability (Table V). However, in the $\mathrm{F}_{3: 4}$ generation under the same conditions, heritability was significantly different from zero, although of small magnitude $(6.06 \%)$. On the other hand, during the dry season of 1997, when considering selection in $\mathrm{F}_{2: 4}$ in Patos de Minas and evaluation in $\mathrm{F}_{2: 4}$ in Lavras, the realized heritability was high. High values for the realized heritability were also obtained during the dry season of 1997, when selecting in $F_{2: 4}$ in Lavras and evaluating $F_{2: 4}$ in Patos de Minas. When considering the $\mathrm{F}_{3.5}$ generation selected in Patos de Minas and evaluated in Lavras, both during the dry season of 1997 , an $11.9 \%$ realized heritability was obtained. However, when the situation was inverted, in other words, with selection in Lavras and evaluation in Patos de Minas, the realized heritability was only $1.1 \%$. In the Carioca x FT-Tarumã crossing, during the

Table II - Description of the experiments in which bean families were evaluated.

\begin{tabular}{|ccccccc|}
\hline $\begin{array}{c}\text { Experiment } \\
\text { number }\end{array}$ & Crossing & $\begin{array}{c}\text { Family } \\
\text { type }\end{array}$ & $\begin{array}{c}\text { Number of } \\
\text { families evaluated }\end{array}$ & $\begin{array}{c}\text { Statistical design/ } \\
\text { number of replications }\end{array}$ & Location & Sowing date \\
\hline 1 & Carioca-MG x H-4 & $\mathrm{F}_{2: 3}$ & 107 & Lattice/2 & Lavras & July 1996 \\
& & $\mathrm{F}_{3: 4}$ & 118 & Lattice/2 & Lavras and & February 1997 \\
& Carioca-MG x H-4 & $\mathrm{F}_{2: 4}$ & 107 & 118 & Latos de Minas & February 1997 \\
3 & Carioca x FT-Tarumã & $\mathrm{F}_{3: 5}$ & 98 & Lattice/3 & Lavras & February 1997 \\
& Carioca x FT-Tarumã & $\mathrm{F}_{2: 3}$ & 64 & & & \\
& & $\mathrm{~F}_{2: 3} \mathrm{RC}_{1}$ & 64 & & & \\
& & $\mathrm{~F}_{2: 3} \mathrm{RC}_{2}$ & 64 & & & \\
\end{tabular}


Table III - Estimates of mean and variance components for some traits related to bean plant architecture obtained from the Carioca-MG x H-4 and Carioca x FT-Tarumã crosses.

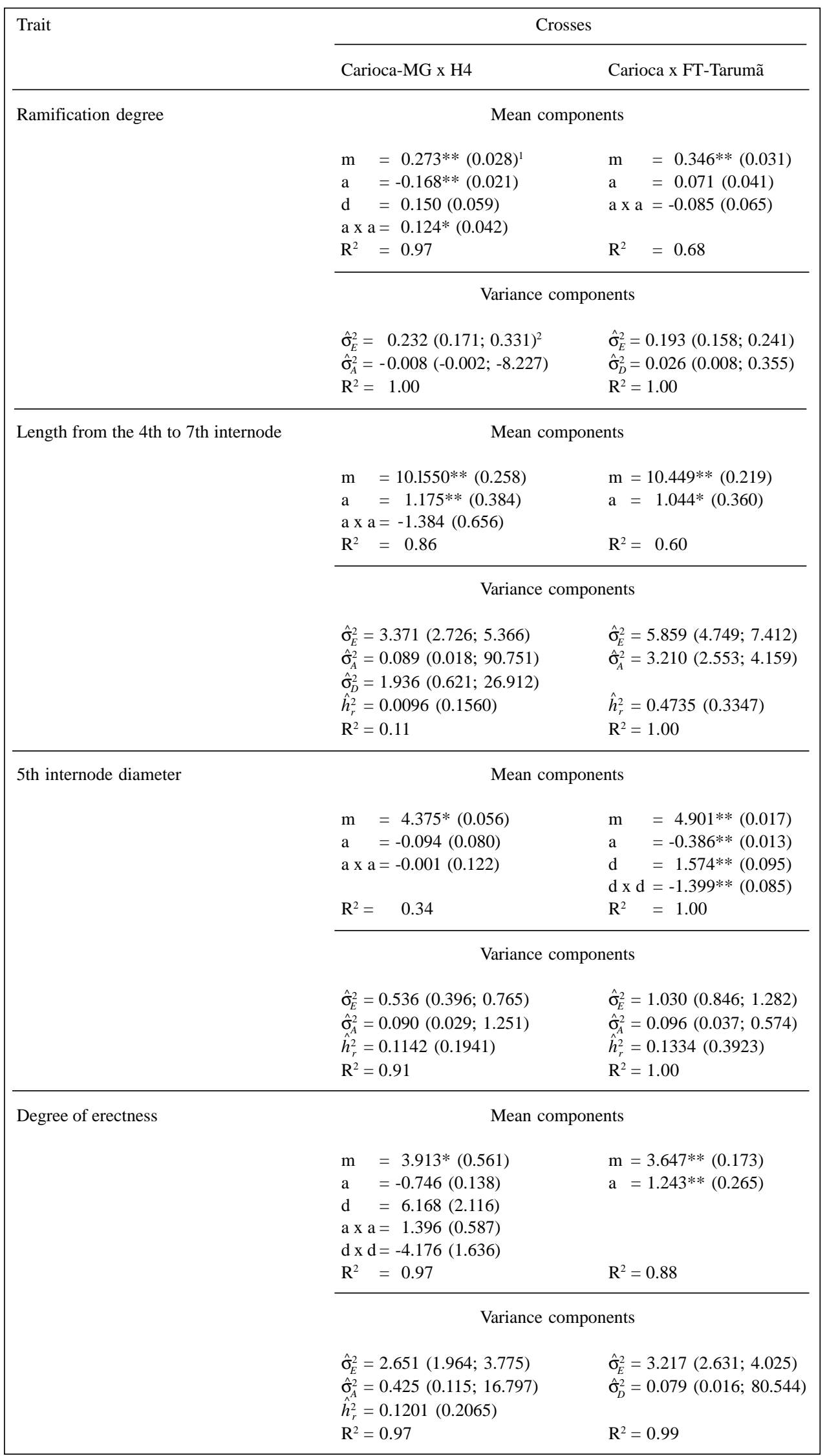


Table III continued

\begin{tabular}{|c|c|c|}
\hline \multirow[t]{2}{*}{ Trait } & \multicolumn{2}{|c|}{ Crosses } \\
\hline & Carioca-MG x H4 & Carioca x FT-Tarumã \\
\hline \multirow[t]{5}{*}{ Height of insertion of the first pod } & \multicolumn{2}{|c|}{ Mean components } \\
\hline & $\begin{aligned} \mathrm{m} & =2.685^{* *}(0.394) \\
\mathrm{d} & =5.787(2.145) \\
\mathrm{dxd} & =-3.565(2.095) \\
\mathrm{R}^{2} & =0.80\end{aligned}$ & $\begin{array}{l}\mathrm{m}=5.881 * *(0.093) \\
\mathrm{a}=-0.880 *(0.107) \\
\mathrm{d}=-0.319(0.276) \\
\mathrm{R}^{2}=0.94\end{array}$ \\
\hline & \multicolumn{2}{|c|}{ Variance components } \\
\hline & $\begin{array}{l}\hat{\sigma}_{E}^{2}=5.606(4.086 ; 8.170) \\
\hat{\sigma}_{D}^{2}=5.539(4.156 ; 7.753) \\
R^{2}=0.91\end{array}$ & $\begin{array}{l}\hat{\sigma}_{E}^{2}=15.10(12.820 ; 19.424) \\
\hat{\sigma}_{A}^{2}=1.363(0.489 ; 11.252) \\
h_{r}^{2}=0.1176(0.3818) \\
R^{2}=1.00\end{array}$ \\
\hline & $\mathrm{R}^{2}=0.91$ & $\mathrm{R}^{2}=1.00$ \\
\hline
\end{tabular}

${ }^{1}$ Standard error of the estimate; ${ }^{2}$ Low and high limits of the estimate; *Significant at the $5 \%$ level; **Significant at the $1 \%$ level.

Table IV - Average values of degree of erectness, their amplitudes, genetic variances and heritabilities, estimated for the bean families evaluated in the experiments.

\begin{tabular}{|c|c|c|c|c|}
\hline Generation & Degree of erectness ${ }^{1}$ & Amplitude & $\hat{\sigma}_{G}^{2}$ & $\hat{h}_{a}^{2}$ \\
\hline Carioca-MG $\left(\mathrm{P}_{1}\right)$ & 5.0 & & & \\
\hline $\mathrm{H}-4\left(\mathrm{P}_{2}\right)$ & 5.8 & & & \\
\hline Between $\mathrm{F}_{3}$ families of $\mathrm{F}_{2}\left(\mathrm{~F}_{2: 3}\right)$ plants & 5.0 & $2.2-8.8$ & 0.642 & $0.3914 \pm 0.1030$ \\
\hline Between $\mathrm{F}_{4}$ families of $\mathrm{F}_{3}\left(\mathrm{~F}_{3: 4}\right)$ plants & 5.5 & $2.8-8.2$ & 0.423 & $0.2981 \pm 0.1151$ \\
\hline Carioca-MG $\left(\mathrm{P}_{1}\right)$ & 3.2 & & & \\
\hline $\mathrm{H}-4\left(\mathrm{P}_{2}\right)$ & 4.3 & & & \\
\hline Between $\mathrm{F}_{4}$ families of $\mathrm{F}_{2}\left(\mathrm{~F}_{2: 4}\right)$ plants & 3.6 & $2.2-6.8$ & 0.197 & $0.6006 \pm 0.0769$ \\
\hline Between $F_{5}$ families of $F_{3}\left(F_{3: 5}\right)$ plants & 3.5 & $2.2-6.2$ & 0.132 & $0.4407 \pm 0.1034$ \\
\hline Carioca $\left(\mathrm{P}_{1}\right)$ & 8.5 & & & \\
\hline FT-Tarumã $\left(\mathrm{P}_{2}\right)$ & 3.5 & & & \\
\hline Between $\mathrm{F}_{3}$ families of $\mathrm{F}_{2}\left(\mathrm{~F}_{2: 3}\right)$ plants & 5.8 & $2.8-8.8$ & 1.136 & $0.5159 \pm 0.0998$ \\
\hline Between $\mathrm{F}_{3}$ families of $\mathrm{F}_{2} \mathrm{RC}_{1}\left(\mathrm{~F}_{2: 3} \mathrm{BC}_{1}\right)$ plants & 6.7 & $3.2-9.2$ & 0.939 & $0.4683 \pm 0.1095$ \\
\hline Between $\mathrm{F}_{3}$ families of $\mathrm{F}_{2} \mathrm{RC}_{2}\left(\mathrm{~F}_{2: 3} \mathrm{BC}_{2}\right)$ plants & 5.0 & $2.2-8.2$ & 0.904 & $0.4588 \pm 0.1152$ \\
\hline Carioca $\left(\mathrm{P}_{1}\right)$ & 7.4 & & & \\
\hline FT-Tarumã $\left(\mathrm{P}_{2}\right)$ & 4.3 & & & \\
\hline Between $\mathrm{F}_{4}$ families of $\mathrm{F}_{3}\left(\mathrm{~F}_{3: 4}\right)$ plants & 5.7 & $2.2-7.8$ & 0.333 & $0.3528 \pm 0.1153$ \\
\hline
\end{tabular}

${ }^{1}$ Scale of 1 to 9 : value 1 corresponded to the most erect plant and value 9 to the most prostrate.

winter of 1996 in Lavras, selection of $\mathrm{F}_{3}$ plants and evaluation of $\mathrm{F}_{3: 4}$ families presented realized heritability of $7.7 \%$.

\section{DISCUSSION}

In order to obtain erect bean plants, some problems need to be solved. First, the trait or traits that are associated with erect plants need to be identified. Adams (1973) listed a series of traits that determine an erect plant. He stated that the cultivar with an ideal plant architecture is the one having strong, thick stems, so that water trans- port is the best possible and, above all, the plants become resistant to lodging. Adams (1973) also stated that cultivars with erect plant architecture have smaller leaves. He indicated a positive correlation between leaf size and bean size, but this correlation is not complete, thus allowing selection for bean size. Other morphological traits were used in studies of bean plant architecture by Acquaah et al. (1991), Kornegay et al. (1992) and Collicchio et al. (1997). Of the traits evaluated in our work, internode length had the best agreement between the estimated mean components and the variance components. The additive effect 
Table V - Estimates of realized heritabilities between bean families for the plant architecture value.

\begin{tabular}{|c|c|c|c|c|c|c|c|c|}
\hline \multirow[t]{2}{*}{ Cross } & \multicolumn{3}{|c|}{ Selection } & \multicolumn{3}{|c|}{ Evaluation } & \multirow{2}{*}{$\begin{array}{l}\text { Selection } \\
\text { index }(\%)\end{array}$} & \multirow{2}{*}{$\begin{array}{c}\mathrm{h}^{2} \text { realized } \\
(\%)\end{array}$} \\
\hline & Generation & Season & Location & Generation & Season & Location & & \\
\hline \multirow[t]{6}{*}{ Carioca-MG x H-4 } & $\mathrm{F}_{2 \cdot 3}$ & winter/96 & Lavras & $\mathrm{F}_{2: 4}$ & dry season/97 & Patos and Lavras & 10 & 0 \\
\hline & $\mathrm{F}_{3: 4}^{2: 3}$ & winter/96 & Lavras & $\mathrm{F}_{3: 5}^{2: 5}$ & dry season/97 & Patos and Lavras & 10 & 6.06 \\
\hline & $\mathrm{F}_{2: 4}^{3: 4}$ & dry season/97 & Patos & $\mathrm{F}_{2: 4}^{3: 5}$ & dry season/97 & Lavras & 10 & 51.37 \\
\hline & $\mathrm{F}_{3.5}^{2: 4}$ & dry season/97 & Patos & $\mathrm{F}_{3.5}^{2: 5}$ & dry season/97 & Lavras & 10 & 11.92 \\
\hline & $\mathrm{F}_{2 \cdot 4}^{3.5}$ & dry season/97 & Lavras & $\mathrm{F}_{2 \cdot 4}^{3: 4}$ & dry season/97 & Patos & 10 & 22.98 \\
\hline & $\mathrm{F}_{3: 5}^{2: 4}$ & dry season/97 & Lavras & $\mathrm{F}_{3: 5}^{2: 4}$ & dry season/97 & Patos & 10 & 1.09 \\
\hline Carioca x FT-Tarumã & $\mathrm{F}_{3}$ & winter/96 & Lavras & $\mathrm{F}_{3: 4}$ & dry season/97 & Lavras & 15 & 7.68 \\
\hline
\end{tabular}

was predominant for internode length, indicating the possibility of successful selection. Similar results were obtained by Santos and Vencovsky (1986), who used a diallel scheme to evaluate segregant populations. However, heritability estimated by those authors was higher (69.0\%).

Another problem is the visual evaluation of plant architecture and subsequent classification on a scale of grades. This is particularly difficult when evaluation at an individual level is tried. The procedure is more coherent when considering families and using more than one evaluator. Marques Junior et al. (1997) used several important bean traits, including plant architecture, in order to determine the efficiency of visual evaluation of traits through a scale of values. This evaluation system had good precision, indicating the efficiency of this procedure, which is frequently adopted by plant breeders. They also commented that when using a grading scale of smaller breadth, that is, 1 to 5 instead of 1 to 9 , the values given to the same treatment by different evaluators coincide more.

Degree of erectness in individual plants was evaluated in previously harvested dry plants which, without any doubt, masked manifestation of the trait. There was little variation and estimated heritabilities were of small magnitude. In addition, they were associated with high error estimates. It can be concluded that evaluation of this trait should not be performed at an individual level. When a scale of degree of erectness was used to evaluate segregating families, experimental precision was low (variation coefficient on average, $21 \%$ ).

The main problem in breeding programs for plant architecture is the effect of the environment. With high humidity, temperatures and/or organic material, the plant presents greater vegetative development, even causing lines that were erect under other conditions to become prostrate. The opposite was observed when these factors were not present, making good discrimination of lines impossible. Collicchio (1995) found a deterioration in degree of erectness when plants were sown in October and November, when higher temperatures and rain fall are registered.

FT-Tarumã parents had the most consistent erect plant architecture possible, that is, they maintained the desired phenotype for the trait under all the conditions tested. On the other hand, Carioca-MG, chosen not only for its plant architecture but mainly for bean type, proved to be unstable and, in some environments, its degree of erectness did not differ as much as desired from the other parent. Therefore, plant and/or family segregation was smaller, which reduced the amplitude of variation of the trait and the genetic variance estimate. Use of the FTTarumã cultivar as a parent in programs aiming to obtain erect plant architecture, in principle, is a good strategy for the reasons already given. It is worth adding that if the objective is to obtain an erect cultivar with grains of the Carioca type, the plant breeder could have serious difficulties since grain color is controlled by many genes, probably an even greater number than that involved in plant architecture (Leakey, 1988). Thus, the plant breeder should try to choose a strategy that makes the process more efficient.

Under high heat and humidity conditions, plant development is improved. Non-erect plants become prostrate and fall over neighboring ones, making even the researcher's passage between the plots difficult during evaluations. The solution would be to use larger plots with borders. However, when more than 100 families are evaluated, as was the case in this experiment, area can be a limitation and the use of larger plots with borders becomes impossible. The quantity of seeds necessary for each family, especially in the first generations, can also limit the use of larger plots.

This can explain the poor agreement observed between heritability estimates based on variance components and realized heritability. The latter, in some cases, was null. It was especially common when realized heritability was estimated from the average performance of the families evaluated in different generations $\left(\mathrm{F}_{2: 3}\right.$ and $\left.\mathrm{F}_{2: 4}\right)$. It is evident that heritability is largely influenced by the genotype $\mathrm{x}$ environment interaction. When evaluations were performed in the same generation but at other locations, there was little interaction, and heritability was relatively high. Heritability was greatest when the Patos de Minas evaluation, in which genetic variation was greater, was used as a reference.

These results emphasize that plant architecture is highly influenced by the environment. Thus, breeding pro- 
grams that use the bulk method with families derived from $\mathrm{F}_{2}$ plants should select families based on the average of three or more evaluations, performed not only during the rainy season harvest, as suggested by Collicchio (1995), but also during other seasons. This author recommended that plants be evaluated in environmental conditions unfavorable to plant architecture. Cultivars that remain erect under adverse conditions would also remain erect under conditions that promote plant architecture improvement. Another fact considered important by Collicchio (1995) for plant architecture selection during the rainy season was that an erect plant architecture becomes more important since it is likely that harvest coincides with rainy periods. An erect plant architecture reduces pod contact with the soil, such that harvest losses are smaller.

\section{ACKNOWLEDGMENTS}

Research was supported by FAPEMIG, Minas Gerais, Brazil.

\section{RESUMO}

O porte mais ereto das plantas tem sido uma das exigências nas novas cultivares de feijão de feijoeiro. Visando obter maiores informações sobre o controle genético de caracteres relacionados ao porte das plantas, foi realizado esse trabalho no período de agosto de 1995 a julho de 1997 nas regiões sul e Alto São Francisco em Minas Gerais. Inicialmente procedeu-se às análises de plantas individuais dos genitores e de diferentes gerações segregantes dos cruzamentos Carioca-MG x H-4 e Carioca-MG x FT-Tarumã. Nesses experimentos, além da nota de porte, foram avaliados os caracteres grau de ramificação, comprimento de entre-nós, diâmetro de entre-nós e altura de inserção da primeira vagem. Foram estimados os componentes de média e de variância e a herdabilidade ao nível de indivíduos. Posteriormente foram avaliadas famílias derivadas de plantas $\mathrm{F}_{2} \mathrm{ou}$ $\mathrm{F}_{3}$ dos mesmos cruzamentos considerando a nota de porte. Foi estimada a variância genética e fenotípica entre médias das famílias, as herdabilidades utilizando os componentes de variância e a herdabilidade realizada. Constatou-se que entre os caracteres morfológicos associados ao porte do feijoeiro o comprimento dos entre-nós foi o que mostrou maior variação, havendo predominância do efeito aditivo no controle do caráter. A avaliação do porte por meio de notas utilizando plantas indi- viduais revelou ser de baixa eficiência. Contudo, quando se utilizaram famílias, apesar da acentuada influência do ambiente na expressão do caráter, as estimativas dos parâmetros genéticos evidenciaram a possibilidade de sucesso com a seleção, especialmente se esta for realizada após a avaliação em algumas gerações e/ou ambientes.

\section{REFERENCES}

Acquaah, G., Adams, M.W. and Kelly, J.D. (1991). Identification of effective indication of erect plant arquitecture in dry bean ideotype. Crop Sci. 31: 261-264.

Adams, M.W. (1973). Plant architecture and physiological efficiency in the field bean. In: Potentials of Field Beans and Other Legumes in Latin America. CIAT, Cali, pp. 266-278.

Brothers, M.E. and Kelly, J.D. (1993). Interrelationship of plant architecture and yield components in pinto bean ideotype. Crop Sci. 33: 12341238.

Collicchio, E. (1995). Associação entre o porte da planta do feijoeiro e o tamanho de grãos. Master's thesis, Universidade Federal de Lavras, Lavras.

Collicchio, E., Ramalho, M.A.P. and Abreu, A. de F.B. (1997). Associação entre o porte da planta do feijoeiro e o tamanho dos grãos. Pesqui. Agropecu. Bras. 32: 297-304.

Davis, D.W. and Frazier, W.A. (1966). Inheritance of some growth habit components in certain types of bush lines of Phaseolus vulgaris $\mathrm{L}$. Proc. Am. Soc. Hortic. Sci. 88: 384-392.

Fehr, W.R. (1987). Principles of Cultivar Development: Theory and Technique. MacMillan, New York.

Kornegay, J., White, J.W. and Cruz, O.O. de la (1992). Growth habit and gene pool effects on inheritance of yield in common bean. Euphytica 62: $171-180$

Leakey, C.L.A. (1988). Genotypic and phenotypic markers in common bean. In: Genetics Resources of Phaseolus Beans (Gepts, P., ed.). Kluwer Academics Publishers, Wageningen, pp. 245-327.

Marques Junior, O.G., Ramalho, M.A.P., Ferreira, D.F. and Santos, J.B. dos (1997). Viabilidade do emprego de notas na avaliação de alguns caracteres do feijoeiro (Phaseolus vulgaris L.). Rev. Ceres 44: 411-420.

Mather, K. and Jinks, J.L. (1984). Introdução à Genética. Sociedade Brasileira de Genética, Ribeirão Preto.

Ramalho, M.A.P., Santos, J.B. dos and Zimmermann, M.J. de O. (1993). Genética Quantitativa Aplicada em Plantas Autógamas: Aplicações ao Melhoramento do Feijoeiro. Editora da Universidade Federal de Goiânia, Goiânia.

Santos, J.B. dos and Vencovsky, R. (1986). Controle genético de alguns componentes do porte da planta em feijoeiro. Pesqui. Agropecu. Bras. 21: $957-963$

Singh, S.P. (1991). Bean genetics. In: Common Beans - Research for Crop Improvement (Schoonhoven, A.V. and Voysest, O., eds.). CIAT, Cali, pp. 55-118.

(Received May 27, 1998) 